IP Periodica Polytechnica

Social and Management

Sciences

24(1), pp. 14-24, 2016

DOI: $10.3311 /$ PPso. 8236

Creative Commons Attribution (i)

RESEARCH ARTICLE

\section{The Level of Use of Project Management Methods, Techniques and Tools and Their Impact on Project Success - Selected Region of Czech Republic}

\author{
Radek Doskočil ${ }^{1 *}$
}

Received 14 May 2015; accepted after revision 28 July 2015

\begin{abstract}
The paper deals with the issue of project modelling, specifically with the practical use of methods, techniques and tools of project management in relation to its success. The aim of this paper is to examine the level of use of methods, techniques and tools in the management of projects and their impact on project success. To fulfil the aim of the paper, a questionnaire survey was carried out in the form of a guided interview, and three statistical hypotheses defined $(\overline{H 1}, \overline{H 2}, \overline{H 3})$. A population was identified and then a selective sample, on which the survey was conducted. The primary data acquired were statistically evaluated and the defined hypotheses statistically verified. Conclusions of the testing of hypotheses by statistical testing showed that there were dependencies between defined statistical variables of individual statistical hypotheses $(\overline{H 1}$, $\overline{H 2}, \overline{H 3})$. On the basis of the results of the overall survey, it can be summarized that in the context of the application of selected project management methods, techniques and tools, companies make certain mistakes in the management of their projects, which have an impact on project success.
\end{abstract}

\section{Keywords}

Project management, project success, methods, techniques, tools

\section{Introduction}

With increasing complexity and laboriousness of making changes or creating new values, the need of their effective planning and management also increases. In this respect, project management (Sanjuan and Froese, 2013; PMI, 2013; AXELOS, 2013; Müller and Turner, 2007; IPMA, 2006) is an ideal means. Risks related to failures to meet deadlines or budgets still exist, and if they materialize, they may entail catastrophic impacts for an entity involved.

Nowadays the theme of project management is very topical, as the application of project management principles keeps expanding also into areas which bear only basic features of projects; they, however, occupy a significant position even in these areas (Relich, 2015).

This paper aims to identify the level of utilization of methods, techniques and tools in the management of projects, and their impact on project success.

The thematic focus of this paper concentrates at the same time on the area of project modelling (Lacko, 2001). In everyday project practice, a project team often gets into situations where they have to face various project-related decisions. In many cases, these decisions can be classified as serious, as the consequences resulting from an incorrect decision may have disastrous consequences for the project. For this reason, project teams naturally make efforts to minimize consequences of incorrect or erroneous decisions. With regard to turbulent and intercultural environments of current, usually complex projects, these endeavours are very complicated. The use of a modelling technique is a possible tool for decision support. Modelling allows project teams to get valuable information to support their future decisions, i.e. decisions regarding, for example, projects that are still in the phase of design, and deepens knowledge on the functioning of the modelled system - of the originals. A significant benefit is brought about by a possibility of experimenting with the model, which can be repeated (simulations), during which the conditions of the experiment are varied and the change in the model behaviour is monitored. Authors Tamay and Gage present simulation software for comprehensive modelling based on the MATLAB ${ }^{\circledR}$ and Simulink applications, designed for the
${ }^{1}$ Department of Informatics, Faculty of Business and Management, Brno University of Technology, Kolejní 2906/4, 61200 Brno, Czech Republic

${ }^{*}$ Corresponding author, e-mail: doskocil@fbm.vutbr.cz 
aviation industry. The tool is designed for people from different areas of research and development, who carry out simulations of models, and serves for simplification and consolidation of joint efforts of these stakeholders. This can lead to more efficient workflows (acceleration - e.g. shortening the development time; more accuracy - e.g. of development results) between relevant project teams and/or individuals. This is achieved through a single graphical user interface, in which the project manager and the member of a development team may simulate various aspects of the project model (Tamay and Gage, 2012).

\section{Theoretical background}

Definition of project success is various based each authors (Serrador and Pinto, 2015; Judgev and Müller, 2005; CookeDavies, 2002).

The following metrics are usually considered as the criteria of project success (Joslin and Müller, 2015):

- The project met the scope, objectives and costs defined (Atkinson, 1999).

- If these criteria are met, the project can be considered as successful, although some "experts" have doubts with respect to this trivial metrics.

- The customer was satisfied with the project.

- The project can be also considered a success even if some of the aspects of the previous criterion are not met, but the customer is satisfied with the main aspects of the project. This criterion is becoming increasingly effective and many organizations nowadays focus on the evaluation of customers' satisfaction with the project. They use the information obtained as a basis for overall evaluation of project success.

- The output of the project has fulfilled the main purpose of the project.

- If the implementation of the project has fulfilled the main purpose of the project despite the fact that some of the criterions of the 'Triple Imperative' were not met, this project can be considered a success. Specifically, if the outcome of the project was, for example, streamlining certain manufacturing processes, which would ultimately lead to financial savings, this project will be successful, even though, for example, the project duration is prolonged compared to the plan or the project budget is exceeded (Doležal et al., 2012).

The issue of project success is also a scientific goal for some authors (Khan and Rasheed, 2015; Kemmeter, 2014, Schibi, 2013 etc.). The research of authors Berssaneti and Carvalho analyzes the relation between project management maturity and the project success in Brazilian organizations. The results show that project management maturity is significantly related to all vertices of the triple imperative dimensions of success. However, it is not related to the customer satisfaction dimension (Berssaneti and Carvalho, 2015). The research of authors Todorović et al. presents a project success analysis framework, which can improve knowledge management in project environment. Research results have confirmed that a project success analysis, presented through the definition of critical success factors, key performance indicators and performance-measuring process has a positive influence on knowledge acquisition and transfer in project environment (Todorović et al., 2015). The research of authors Serra and Kunc presents the results of a survey to practitioners in Brazil, United Kingdom and United States evaluating the impact of Benefits Realisation Management (BRM) practices on project success rate. The results show, that BRM practices are positive predictors to project success on the creation of strategic value for the business (Serra and Kunc, 2015). The paper by McKay and Ellis presented a study in which the relationship among knowledge sharing processes at the organizational level (organizational learning factors, the unit level, project learning practices) and the success of the IT project (McKay and Ellis 2014) were examined. The paper by authors Chipulu et al. presented the impact of cultural values on the importance individuals assign to project success/failure factors (Chipulu et al., 2014). The research by authors Kloppenborg et al. presented the role of the executive sponsor in achieving project success. Results provide knowledge that will help executive sponsors decide how to invest their limited time and resources (Kloppenborg, Tesch, Manolis, 2014). Authors Mazur et al. present a model of the associations between major project managers' personal attributes and project success in the context of the Australian Defence industry. In this model, emotional intelligence, cognitive flexibility and systemic thinking were hypothesized to relate to project success, mediated by internal and external stakeholder relationships. This model was tested in an online survey with 373 major project managers. Emotional intelligence and cognitive flexibility were found to be related to the development, quality and effectiveness of major project managers' relationships with both internal and external stakeholders; and these in turn were associated with their ratings of project success (Mazur, Pisarski, Chang, Ashkanasy, 2014).

In the Czech Republic, authors engaged in the research in the area of use of traditional methods and tools of project management were Smolíková and Koleňák (Koleňák and Smolíková, 2013; Koleňák and Smolíková, 2012).

Mainly traditional methods and techniques used in project management are considered as project management methods and techniques. For example Critical Path Method (CPM), PERT Method (Berganitiños and Vidal-Puga, 2009; Pérez et al., 2005), Gantt Chart, Critical Chain Method (Goldratt, 2011), Resource Histogram, (Rosenau, 2007), Logical Framework Method, etc. (Doležal et al., 2012).

Software means to support project planning and management are considered project management tools; the tools usually work with a number of the above methods and techniques. Currently the global standard for project planning and management is the Microsoft Project application, which is constantly evolving; the current version is MS Project 2013 (Kubálek and 
Kubálková, 2010; Dvořák et al., 2011). As to other products designed to support project planning and management, we can mention - for example - applications Primavera Project Planner, Powerproject, OpenProj, etc.

Advance methods used for project modelling especially include methods falling into the category of soft computing, such as fuzzy logic or artificial neural networks (Dostál, 2011). Application of fuzzy logic is based on the fuzzy set theory (Zadeh 1965; Zimmermann 2001). Authors Kuchta, Chanas and Zielinski, Oliveros and Fayek, Bushan and Ravi, Doskočil and Doubravský presented fuzzy sets using fuzzy numbers to obtain critical paths of project (Kuchta 2001; Chanas and Zielinski 2001; Oliveros, Fayek 2005; Bushan and Shankar, 2012; Doskočil and Doubravský 2013). The research by author Relich presented project duration and cost estimated by a fuzzy neural system that uses data of completed projects stored in an ERP system (Relich 2013). Data mining techniques, artificial neural networks and the fuzzy neural system are used to identify relationships between the duration of the project phase and other data stored in the information system of an enterprise (Relich, Muszyński, 2014). Authors Naeni, Shadrokh, Salehipour present in their article a fuzzy model based on EVM, advantageously analyzing EVM indices concerning time and costs of the project in the conditions of uncertainty. They emphasize that in the evaluation of the status of the project, the proposed model is very useful with regard to the uncertainty associated with life phases of the project. The issue is presented on a case study (Naeni et al., 2011). The article of authors Nieto-Morote and Ruz-Vila presents the methodology of risk assessment on the basis of the fuzzy set theory, which is an effective tool for dealing with subjective assessments. The proposed methodology is based on the knowledge and experience gained from many experts. Risk factors are evaluated using a qualitative criterion in the form of trapezoidal fuzzy numbers. Fuzzy numbers describe uncertainty of variables at the language level (Nieto Morote-and-Ruz Vila, 2011).

\section{Methodology}

Statistical hypotheses were defined to meet the defined goal of the paper:

- $\overline{\mathbf{H} 1}$,There is a dependence between the integrated method of project management ${ }^{1}$ and project success."

- $\overline{\mathbf{H} 2}$,There is dependence between the ability to apply an integrated method of project management and the level of using software support in project management."

- $\overline{\mathbf{H} 3}$,There is dependence between the level of using software support in project management and the ability to apply the modelling technique in the area of project management.“

1 The integrated method of project management is understood here as the ability to apply an interconnected method of implementing main areas of project management at least at the level of the management of time, resources and costs.
To meet the aim of the research, methods of quantitative and qualitative research were used. Quantitative research was conducted through a targeted survey questionnaire. Quantitative research was supplemented by qualitative research in the form of structured and semi-structured interviews.

The questionnaire contained 28 questions, designed to best capture key aspects of the issue dealt with and provide a possibility to test the statistical hypotheses established. Simplicity and relative brevity were important factors in its creation, as they had an impact on the willingness of respondents to complete it. The questionnaire included questions with one or more choices of optional answers. The questionnaire essentially consisted of three sub-sections. Section one comprised questions 1 to 4 and focused on acquiring basic information about enterprises, such as the size of the company, its core business, etc. The second section was made up of questions 5 to 11 , and was aimed at obtaining information on the level of project management, i.e. whether the company had certifications in project management, what methods, techniques and tools it mainly used in project management, what the main causes of project failure were, etc. The third section consisted of questions 12 to 28 , and was aimed at obtaining information on the level of use of the MS Project application, as the software application most used in project management.

Before the research was commenced, thorough consideration was given to the set examined. The goal was to identify such a population and then a selective sample, which would have sufficient explanatory power for the issue dealt with. Factors that could have determined the targeting of the research and thus reduced the circle of respondents were - for example - the company size, the sphere of activity, geographical location, etc. With regard to the aim and object of the research, a decision was made after thorough consideration to carry out the research on selected companies in the Vysočina Region (one of the regions of the Czech Republic). The main reason was that the researcher had relatively good knowledge of the region, which increased the probability of obtaining relevant data by means of survey questionnaires and controlled interviews.

To select specific companies for the research, the database of contacts of the CR Technology Profile (Technologický profil ČR [online]) was used, which contains contact details of more than 2000 Czech companies operating in innovation business. The innovative capability of companies, in other words their ability to continually develop and implement effective innovation processes, is - inter alia - conditioned by active application of project management. Due to this precondition, this database was suitable also for the solution of the specified research objective.

The structure of the population (see Table 1) was described by the following factors:

- The geographical aspect - individual districts of the Vysočina Region.

- The aspect concerning scope - the number of companies in the Vysočina Region and its individual districts. 
- The aspect concerning the sphere of activity - industrial classification of economic activities (CZ-NACE).
The identification of the sample was based on the knowledge of the structure of the population (see Table 1). Within the population, the sample was defined taking into consideration

Table 1 Population structure

\begin{tabular}{|c|c|c|c|c|c|c|}
\hline CZ-NACE/districts (region) & Pelhřimov & $\begin{array}{c}\text { Havlíčkův } \\
\text { Brod }\end{array}$ & Jihlava & Třebíč & $\begin{array}{l}\text { Žd'ár nad } \\
\text { Sázavou }\end{array}$ & $\begin{array}{c}\text { Vysočina } \\
\text { Region }\end{array}$ \\
\hline Agriculture & 1 & 1 & 0 & 0 & 0 & 2 \\
\hline Fishing, breeding ponds, associated activities & 0 & 2 & 0 & 0 & 0 & 2 \\
\hline Food and beverage production & 0 & 1 & 1 & 0 & 0 & 2 \\
\hline Textile industry & 0 & 1 & 0 & 0 & 0 & 1 \\
\hline Clothing industry, processing and dying of fur & 0 & 1 & 0 & 0 & 0 & 1 \\
\hline \multicolumn{7}{|l|}{ Tanning and dressing of leather, manufacture of bags, saddles and footwear } \\
\hline brašnářského & 0 & 0 & 1 & 0 & 0 & 1 \\
\hline \multicolumn{7}{|l|}{ a sedlářského zboží a obuvi } \\
\hline Wood and cork industry & 1 & 0 & 0 & 1 & 2 & 4 \\
\hline Pulp, paper and paperboard production & 0 & 0 & 0 & 2 & 0 & 2 \\
\hline Publishing, printing and reproduction & 0 & 0 & 0 & 0 & 1 & 1 \\
\hline Manufacture of chemical products & 1 & 1 & 2 & 0 & 1 & 5 \\
\hline Manufacture of rubber and plastic products & 0 & 1 & 1 & 1 & 4 & 7 \\
\hline Manufacture of other non-metallic mineral products & 0 & 1 & 1 & 0 & 1 & 3 \\
\hline Manufacture of metals including metallurgy processing & 0 & 0 & 0 & 0 & 1 & 1 \\
\hline Manufacture of metal structures & 9 & 7 & 5 & 5 & 7 & 33 \\
\hline Manufacture of machinery and equipment & 7 & 10 & 4 & 5 & 9 & 35 \\
\hline Manufacture of electrical machinery and equipment & 1 & 4 & 7 & 1 & 3 & 16 \\
\hline Manufacture of radio, television and communication equipment and devices & 0 & 1 & 3 & 1 & 1 & 6 \\
\hline Manufacture of medical, precision and optical time-measuring devices & 0 & 1 & 1 & 1 & 2 & 5 \\
\hline Manufacture of two-track vehicles and trailers & 2 & 1 & 16 & 0 & 2 & 21 \\
\hline Manufacture of other transport equipment & 1 & 0 & 0 & 0 & 2 & 3 \\
\hline Manufacture of furniture; other processing industry & 0 & 0 & 0 & 1 & 1 & 2 \\
\hline Construction industry & 2 & 2 & 2 & 4 & 2 & 12 \\
\hline Sale, repair and maintenance of motor equipment and trailers & 3 & 0 & 0 & 0 & 0 & 3 \\
\hline Retail trade, repair of consumer goods & 3 & 4 & 2 & 2 & 8 & 19 \\
\hline Wholesale trade, commission trade & 3 & 10 & 4 & 7 & 4 & 28 \\
\hline Hotels and restaurants & 2 & 1 & 1 & 1 & 1 & 6 \\
\hline Land transport, transport via pipelines & 1 & 1 & 2 & 0 & 1 & 5 \\
\hline Renting of machinery and equipment without operating staff & 1 & 0 & 1 & 1 & 0 & 3 \\
\hline Data processing and related business & 0 & 1 & 2 & 4 & 4 & 11 \\
\hline Research and development & 0 & 5 & 2 & 0 & 0 & 7 \\
\hline Service providing mainly to businesses & 5 & 10 & 3 & 10 & 6 & 34 \\
\hline Education & 0 & 0 & 1 & 1 & 0 & 2 \\
\hline Wastewater and solid waste removal & 0 & 1 & 0 & 0 & 2 & 3 \\
\hline Other services & 0 & 2 & 0 & 0 & 1 & 3 \\
\hline Overall representation of companies [number] & 18 & 28 & 24 & 19 & 28 & 117 \\
\hline
\end{tabular}


traditional properties of the statistical sample. The structure of the sample was described by the same factors as the structure of the population, i.e.

- The geographical aspect - individual districts of the Vysočina Region.

- The aspect concerning scope - the number of companies in the Vysočina Region and its individual districts was set at the level of $40 \%$, i.e. 47 companies; from the point of view of statistics, this level is sufficient (Saunders et al., 2009).

- The aspect concerning the sphere of activity - industrial classification of economic activities (CZ-NACE) that was reflected in the final selection of specific companies in the given district, when companies were favoured, which had the broadest sphere of action according to CZ-NACE.

- The structure of the survey sample is presented by Table 2 .

Table 2 Sample structure

\begin{tabular}{|c|c|c|c|c|c|c|}
\hline & 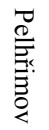 & 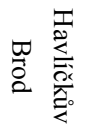 & 茑 & $\begin{array}{l}\underset{7 x}{0} \\
\stackrel{0}{0} \\
\mathscr{\sigma}_{x}\end{array}$ & 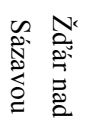 & 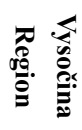 \\
\hline $\begin{array}{c}\text { Representation } \\
\text { of companies } \\
\text { [number] }\end{array}$ & 18 & 28 & 24 & 19 & 28 & 117 \\
\hline $\begin{array}{c}\text { Representation of } \\
\text { companies [\%] }\end{array}$ & 15 & 24 & 21 & 16 & 24 & 100 \\
\hline $\begin{array}{c}\text { Companies } \\
\text { approached } \\
\text { [number] }\end{array}$ & 7 & 11 & 10 & 8 & 11 & 47 \\
\hline
\end{tabular}

The sample defined a circle of respondents who were included in the research. Research performed on the sample, which is a representative sample of the population, has several advantages:

- The results of the research performed on the sample have comparable explanatory power as the results of research conducted on the population.

- The research conducted on the sample, i.e. on a smaller number of respondents, who were - however - selected carefully and in a targeted manner, is of much higher quality and has better explanatory power. With regard to the aim of the research, this quality would not have been achieved by a blanket questionnaire survey, where there would have been a considerable risk of unwillingness of respondents to complete the questionnaire, or the questionnaire would have been completed, but by an incompetent person, which would have reduced the explanatory power almost to zero.

Due to this way of conducting the research, primary data were obtained, which provided valuable input information for further stages of the research; their explanatory power was sufficient.
Evaluation of the data obtained represents an important process consisting of several stages. The data obtained were processed and analyzed using statistical software. In data analysis, selected statistical methods were used, falling into the area of categorial analysis, during which selected methods were used, identifying dependencies between the two-dimensional data set of qualitative variables and the apparatus of statistical hypotheses testing (chi-square test).

The two-dimensional data set of qualitative variables means the situation when their values are expressed in words. If the result of observations or of an experiment is described in words or classified into one of several mutually exclusive categories, we talk about the experiment with a qualitative response. In one experiment, it is possible to simultaneously observe two or more qualitative responses, similar as in one experiment it is possible to measure or observe two or even more random quantities. The result of the whole experiment can be summarized in the so-called contingency table. In our case, the variables of an alternative type were considered, i.e. they assumed only two alternatives, and the special type of a contingency table, the socalled $2 \times 2$ contingency table was therefore used (Kropáč, 2007).

The aim of the test of the independence of qualitative variables is to determine whether relevant two statistical variables are mutually dependent or not. If the dependence is confirmed by the test, the strength of this dependence is also searched. Phases of the testing process correspond to the general procedure of testing statistical hypotheses and are described below.

1. The null hypothesis of the independence of quantitative variables is formulated in the form of

$$
H: p_{i j}=p_{i .} p_{. j} ; i=1,2 ; j=1,2 ;
$$

which means that the product of marginal probabilities from a particular row and a particular column of the contingency table is equal to simultaneous probability in their intersection, which applies to all combinations of row and column indices $i$ and $j$.

An alternative hypothesis $\bar{H}$ formulated in the form of $\bar{H}: p_{i j} \neq=p_{i} p_{\cdot_{j}}$ says that for some pairs of $i ; j$ the said equality does not apply.

2. The following statistics is used as a test criterion:

$$
\chi^{2}=n \frac{\left(n_{11} n_{22}-n_{12} n_{21}\right)^{2}}{n_{1 .} n_{2 .} n_{.1} n_{.2}},
$$

which has asymptotic Pearson distribution with one degree of freedom.

3. Critical field $\mathrm{W}_{\alpha}$ for the chosen significance level $\alpha$ is:

$$
W_{\alpha}=\left\{\chi^{2} ; \chi^{2} \geq \chi_{1-\alpha}^{2}(1)\right\}
$$

4. If the realized value of the test criterion is in the critical field, the null hypothesis at the significance level of $100 \alpha \%$ is dismissed, and the alternative hypothesis accepted. 
The strength of the dependence of statistical variables can be determined using the Cramer's contingency coefficient:

$$
V=\sqrt{\frac{\chi^{2}}{n}}
$$

where $\chi^{2}$ is the test statistic used. The Cramer's contingency coefficient equals zero in case of total independence of the tested variables; if they are totally dependent, it equals one. In other cases, it reaches values in the interval $(0,1)$, while the higher value of this coefficient corresponds to tighter dependence of these variables, while values $n, r$, and $s$ are the same (Kropáč, 2007).

\section{Results}

Primary data obtained from the questionnaires or from 'relevant questions' of the questionnaires served as input information for testing the hypotheses defined. As the 'relevant questions', the questions whose character was related to the hypothesis were considered. Verifying the hypotheses entailed the process of discovering dependencies between qualitative variables, which was carried out by means of statistical methods using the apparatus for testing hypotheses.

Key conclusions of the process of testing individual statistical variables of the defined statistical hypotheses are presented gradually in Table 3 to 8 .

\section{Verification of hypothesis $\overline{\mathrm{H} 1}$}

Alternative hypothesis $\overline{\mathrm{H} 1}$ and null hypothesis $\mathbf{H} 1$ were defined:

$\overline{\mathbf{H 1}}$ : "There is dependence between the integrated method of project management and project success."

H1: "There is no dependence between the integrated method of project management and project success."

The qualitative variable "integrated method of management" is denoted by symbol A. The qualitative variable "success" is marked with symbol B. The significance level is considered at the level of 0.05 .

The data were abstracted in the MS Excel application using selected functions. Table 3 presents the frequency of the occurrence of statistical variables "integrated method of management" and "success".

Table $32 \times 2$ contingency table of frequencies of occurrence of individual alternatives of statistical variables "integrated method of management" and "success"

\begin{tabular}{cccc}
\hline & B1 (No) & B2 (Yes) & Marg. frequen. \\
\hline A1 (No) & 28 & 3 & 31 \\
A2 (Yes) & 6 & 10 & 16 \\
Marg. frequen. & 34 & 13 & 47 \\
\hline
\end{tabular}

In the framework of testing the independence of two qualitative variables, null hypothesis H1 was tested, which describes the situation when statistical variables $\mathrm{A}$ and $\mathrm{B}$ are independent (see Table 4).

Table 4 Result of the test of independence of variables

"integrated method of management" and "success"

Null hypothesis: Variables A and B are independent.

Value of test criterion chikv $=14.716$

Critical value chikv $=3.841$

Test conclusion: Hypothesis rejected

Calculation of Cramer's contingency coefficient: $\mathrm{V}=0.560$

Test results show that the test criterion lies in the critical field, the null hypothesis is therefore rejected and the alternative hypothesis adopted; it is possible to be mistaken in five percent of cases. Test results specifically show that there is dependence between the application of the integrated method of project management and its success. On the basis of the Cramer's coefficient, this dependence is assessed as medium.

\section{Verification of hypothesis $\overline{\mathbf{H} 2}$}

Alternative hypothesis $\overline{\mathrm{H} 2}$ and null hypothesis $\mathbf{H} 2$ were defined:

$\overline{\mathbf{H} 2}$ : "There is dependence between the ability to apply an integrated method of project management and the level of using software support in project management."

H2: "There is no dependence between the ability to apply an integrated method of project management and the level of using software support in project management."

The qualitative variable "integrated method of management" is denoted by symbol A. The qualitative variable "the level of software use" is marked with symbol B. The significance level is considered at the level of 0.05 .

The data were abstracted in the MS Excel application using selected functions. Table 5 presents the frequency of the occurrence of statistical variables "integrated method of management" and "the level of software use".

Table $52 \times 2$ of frequencies of occurrence of individual alternatives of statistical variables "integrated method of management" and "the level of software use"

\begin{tabular}{cccc}
\hline & B1 (No) & B2 (Yes) & Marg. frequen \\
\hline A1 (No) & 31 & 0 & 31 \\
A2 (Yes) & 7 & 9 & 16 \\
Marg. frequen & 38 & 9 & 47 \\
\hline
\end{tabular}


In the framework of testing the independence of two qualitative variables, null hypothesis $\mathrm{H} 1$ was tested, which describes the situation when statistical variables $\mathrm{A}$ and $\mathrm{B}$ are independent (see Table 6).

Table 6 Result of the test of independence of variables "integrated method of management" and "the level of software use"

\begin{tabular}{c}
\hline Null hypothesis: Variables A and B are independent. \\
\hline Value of test criterion chikv $=21.567$ \\
Critical value chikv $=3.841$ \\
\hline Test conclusion: Hypothesis rejected \\
Calculation of Cramer's contingency coefficient: $\mathrm{V}=0.677$
\end{tabular}

Test results show that the test criterion lies in the critical field, the null hypothesis is therefore rejected and the alternative hypothesis adopted; it is possible to be mistaken in five percent of cases. Test results specifically show that there is dependence between the application of the integrated method of project management and the level of using software support in project management. On the basis of the Cramer's coefficient, this dependence is assessed as moderately strong.

\section{Verification of hypothesis $\overline{\mathbf{H} 3}$}

Alternative hypothesis $\overline{\mathrm{H} 3}$ and null hypothesis $\mathbf{H} 3$ were defined:

$\overline{\mathbf{H} 3}$ : "There is dependence between the level of using software support in project management and the ability to apply the modelling technique in the area of project management."

H3: "There is no dependence between the level of using software support in project management and the ability to apply the modelling technique in the area of project management."

The qualitative variable "the level of using software" is denoted by symbol A. The qualitative variable "the ability to apply the modelling technique" is marked with symbol $\mathrm{B}$. The significance level is considered at the level of 0.05 .

The data were abstracted in the MS Excel application using selected functions. Table 7 presents the frequency of the occurrence of statistical variables "integrated method of management" and "the level of using software".

Table $72 \times 2$ contingency table of frequencies of occurrence of individual alternatives of statistical variables "integrated method of management" and "the level of using software"

\begin{tabular}{cccc}
\hline & B1 (No) & B2 (Yes) & Marg. frequen. \\
\hline A1 (No) & 36 & 2 & 38 \\
A2 (Yes) & 6 & 3 & 9 \\
Marg. frequen. & 42 & 5 & 47 \\
\hline
\end{tabular}

In the framework of testing the independence of two qualitative variables, null hypothesis H1 was tested, which describes the situation when statistical variables $\mathrm{A}$ and $\mathrm{B}$ are independent (see Table 8).

Table 8 Result of the test of independence of variables "integrated method of management" and "the level of using software"

\begin{tabular}{c}
\hline Null hypothesis: Variables A and B are independent. \\
\hline Value of test criterion chikv $=6.031$ \\
\hline Critical value chikv $=3.841$ \\
\hline Test conclusion: Hypothesis rejected \\
Calculation of Cramer's contingency coefficient: $\mathrm{V}=0.358$ \\
\hline
\end{tabular}

Test results show that the test criterion lies in the critical field, the null hypothesis is therefore rejected and the alternative hypothesis adopted; it is possible to be mistaken in five percent of cases. Test results specifically show that there is dependence between the application of the level of using software support and the ability to apply modelling technology in the area of project management. On the basis of the Cramer's coefficient, this dependence is assessed as medium.

\section{Discussion}

Primary research conducted in the corporate practice on the basis of the questionnaire survey and structured interviews provided valuable information on the current status and levels of use of selected methods, techniques and tools in project management in relation to project success. The analysis of data obtained on the sample provided information, which is summarized and presented below.

The following conclusions arose from the first section of the questionnaire, which was aimed at obtaining basic data about the companies: According to the 'number of employees' criterion, most of the companies surveyed was categorized as mediumsized (50 to 249 employees) - 18 companies, and large-sized (over 250 employees) - 19 companies. Seven companies were ranked as small-sized (10 - 49 employees), and only 3 companies were categorized as micro-companies ( 1 - 9 employees). In terms of principal business activities, the companies involved were mainly manufacturing companies; the more detailed aspect of the sphere of activity was defined according to the industry classification of economic activities (CZ-NACE), and served as one of the factors in defining the sample. In general, 43 companies surveyed are involved in the production. Three companies deal with both production and trade. The same number of companies stated also the combination of trade and services. Two companies stated as the main activity only trade and only services. As far as the property is concerned, 27 companies reported the Czech ownership, 12 companies foreign participation and 8 companies foreign ownership. As the dominant markets covered, 32 companies reported the national 


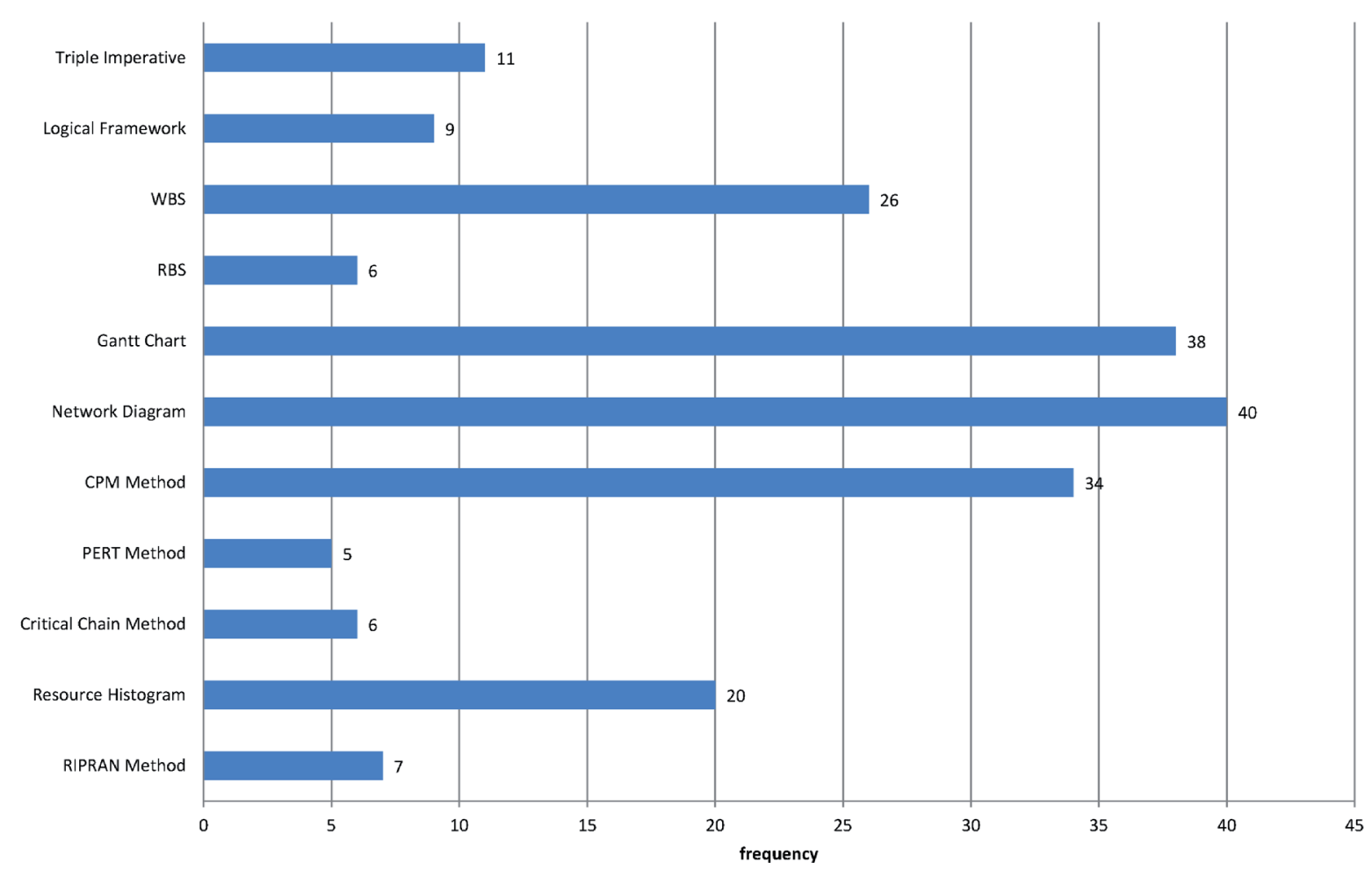

Fig. 1 Distribution uses selected methods and techniques of project management

market of the Czech Republic, 32 companies the market of the European Union, five companies other markets (outside the EU), and four companies the Czech market.

The second section of the questionnaire, aimed at obtaining the information on the level of project management, provided the following conclusions: Of the companies surveyed, 34 companies responded that they did not have any certification in project management, 12 companies did have such certification and one company stated that it did not know. The distribution of using selected methods and techniques in project management in the companies surveyed was as follows (see Figure 1).

Figure 1 shows that most companies use the technique of Gantt Chart and network diagram (Network diagram presents a model of the project - project tasks including the links between them. The methods of time analysis of the project (as e.g. CPM, PERT, MPM methods) can be applied to the constructed network diagram). The most used method of time analysis of the project is the basic CPM method. Only 5 companies stated that on some occasions they had used the PERT stochastic method. A relatively high frequency of use is also reported in relation to the WBS technique and to the resource histogram. The lower utilization rate (in terms of frequencies obtained) is seen in the RIPRAN method, the Critical Chain Method, or the Logical Framework Method. From the above it can be concluded that in the management of their projects, the companies focus much more on the temporal analysis of the project, but considerably less on the resource or cost analysis.

The distribution of factors of the most frequently chosen causes of failure of projects in the companies surveyed was as follows (see Figure 2).
Figure 2 shows that the failure to comply with the project scheduled duration and exceeding the planned project budget were reported as frequent causes of project failure. Another frequent cause included unexpected project risks and changes in the attitude of the project sponsor, or generally poor communication among project stakeholders. Failure to comply with the scheduled project duration was reported most frequently, even though vast majority of companies stated that they used methods and techniques of temporal analysis in project management. Also, 29 respondents stated that in project management, they processed the resource analysis of the project (not always in one application), and 16 respondents said that they used software support in processing the cost analysis. In terms of frequency of use of software tools to support project management, the interviewed respondents indicated that they most commonly used applications MS Excel and MS Project, most often in the design phase of the project (planning and management). Approximately one half of the respondents stated that they used these applications already in the pre-project phase. In contrast, only 5 respondents said that they used software support in the post-project phase. Only 6 companies stated that they used other than the aforementioned applications, and 3 of them used their own company applications, the use of which was more or less mandatorily ordered by their parent companies. The MS Project application was used in different versions (the MS Project 2010 version prevails) and editions, while the Standard edition prevailed.

On the basis of the third section of the questionnaire identifying the levels of use of the MS Project applications, the following conclusions were made: The vast majority of respondent companies perform some of basic settings in the application, 


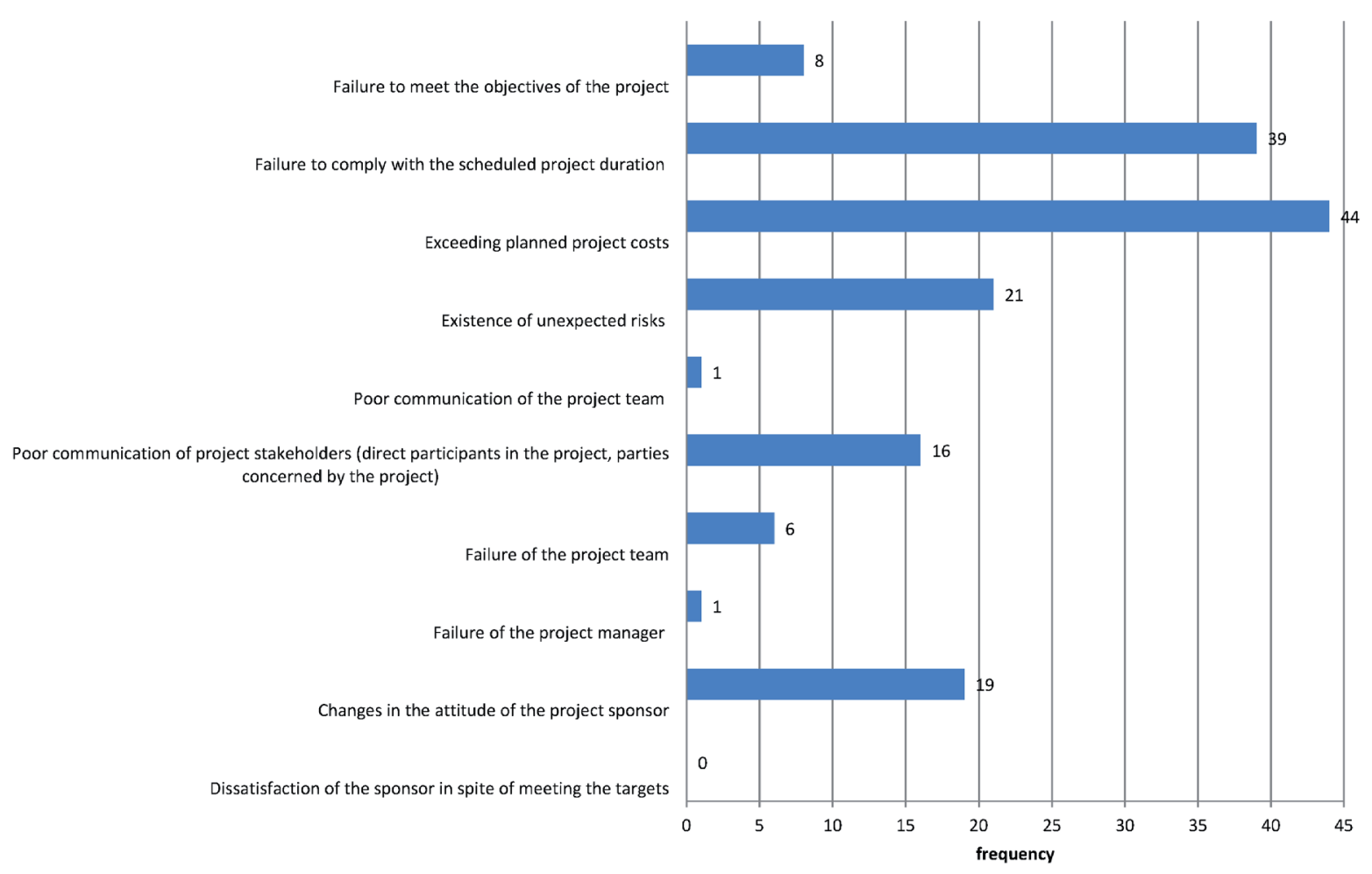

Fig. 2 Distribution of factors of the most common causes of project failure

such as: entering meta information; the setting of working/ non-working time; the setting of the working hours fund; and the setting of planning methods (ASAP, ASLP). However, 22 of the addressed respondents do not enter meta information into the application (the title, subject, project manager). Most companies also use the default setting of the way of planning - ASAP. Approximately one quarter of respondent companies does not carry out the setting of working and non-working time and of the working time fund. These settings, however, are directly linked to the temporal analysis of the project, which can thus be biased. This bias is subsequently transmitted to the resource and cost analysis of the project. Most companies (35) also stated that in planning the projects in the application, they used both manually and automatically scheduled tasks. In tasks planning, approximately 30 companies only used working time units; most frequently they used the link between the tasks of the FS type (Finish - Start); they did not use advance or delay; they did not use restriction of tasks of the FNET, FNLT, MFO type, etc.; and they did not use special calendars of the 'task calendar' or 'resource calendar' types. Cost planning in the application is most often carried out using both fixed costs and variable costs in the form of labour and material resources. The function "Effort drive" for human resource planning, however, is only used by 12 companies. The issue of resource overloading was usually dealt with using the auto-alignment function (19), or was not dealt with at all. Vast majority of companies did not use the Baseline at all. Only 9 companies (mainly those that possessed certification in project management) said that they did use the Baseline. The same companies further stated that they used the EVM method (Earned Value Management)
- either routinely or according to the nature of the project. The issue of shared resources was not used in the application by 26 companies surveyed. Seven companies used the application in the edition of MS Project Server for shared resources management, and 4 companies addressed this issue by using external applications, often using only MS Excel. The reporting of the project was done by about 30 companies in the application using only the pre-defined reports, while about a half of them have sometimes used selected custom reports.

\section{Conclusion}

The aim of the paper was to examine the level of use of methods, techniques and tools in project management and their impact on project success.

On the basis of the results of the primary research conducted including the results of the statistical hypotheses defined, it can be summarized that in the management of their projects in the context of the application of selected methods, techniques and tools of project management, companies (in the Vysočina Region) make certain mistakes, which have an impact on project success.

The use of modelling techniques in the area of project management is not widespread in practice - with few exceptions of traditional use of the project model in the form of a network diagram. However, some problems are still experienced even in this traditional project modelling, which are associated with the use of selected traditional methods and techniques of project management in the context with software support used mainly in the phase of project planning. The most commonly used software to support management, the MS Project application, is in practice usually used only marginally and often incorrectly. There are 
several causes to this. Usually the basic principle of the operation of the application was not understood, or the basic principle of traditional techniques and methods of project management, which the application works with, was not understood either. Incorrect setting of initial parameters of the project (working/ non-working time, project calendars, resources, tasks), failure to comply with the properties of the network diagram, failure to consider the results of the temporal analysis in relation to resource analysis and other analyses of the project are just a few selected, frequently recurring problems. For many users, for example, the reason for and principle of using Baselines is a great unknown. A frequent problem is also the ignorance of the necessity to define the links between tasks, define special calendars, etc. The application is most often used only for processing the project schedule. The resource and cost analysis is usually only carried out without the support of an application, or is processed only partially in the application. This fact poses a great risk of not capturing all key aspects related to the project. An incorrectly or incompletely processed project resource analysis and failure to link it with the project temporal analysis leads to inaccurate determination of project costs and to a number of other errors that affect the success of the project.

\section{Acknowledgement}

This paper was supported by grant FP-S-15-2787 'Effective Use of ICT and Quantitative Methods for Business Processes Optimization' from the Internal Grant Agency at Brno University of Technology.

\section{References}

Atkinson, R. (1999) Project management: cost, time and quality, two best guesses and a phenomenon, its time to accept other success criteria. International Journal of Project Management. 17 (6). pp. 337-342. DOI: 10.1016/S0263-7863(98)00069-6

AXELOS. (2013) Managing Successful Projects with PRINCE2 ${ }^{\circledR}$, TSO, UK.

Berganitiños, G., Vidal-Puga, J. (2009) A Value for PERT Problems. International Game Theory Review. 11 (4). pp. 419-436. DOI: $10.1142 / \mathrm{S} 0219198909002418$

Berssaneti, F. T., Carvalho, M. M. (2015) Identification of variables that impact project success in Brazilian companies. International Journal of Project Management. 33 (3). pp. 638-649. DOI: 10.1016/j.ijproman.2014.07.002

Bushan Rao, P. P., Shankar, N. R. (2012) Fuzzy Critical Path Method Based on Lexicographic Ordering of Fuzzy Numbers. Pakistan Journal of Statistics \& Operation Research. 8 (1). pp. 139-154. DOI: 10.1234/pjsor.v8i1.178

Chanas, S., Zielinski, P. (2001) Critical path analysis in the network with fuzzy activity times. Fuzzy sets and Systems. 122 (2). pp. 195-204. DOI: $10.1016 / \mathrm{S} 0165-0114(00) 00076-2$

Chipulu, M., Ojiako, U., Gardiner, P., Williams, T., Mota, C., Maguire, S., Shou, Y., Stamati, T., Marshall, A. (2014) Exploring the impact of cultural values on project performance The effects of cultural values, age and gender on the perceived importance of project success/failure factors. International Journal of Operations \& Production Management. 34 (3). pp. 364-389. DOI: 10.1108/IJOPM-04-2012-0156
Cooke-Davies, T. (2002) The "real" success factors on projects. International Journal of Project Management. 20 (3) pp. 185-190.

DOI: 10.1016/S0263-7863(01)00067-9

Doležal, J., Máchal, P., Lacko, B., et al. (2012) Projektový management podle IPMA. Grada Publishing, Praha. (in Czech)

Doskočil, R., Doubravský, K. (2013) Critical Path Method based on Fuzzy Numbers: Comparison with Monte Carlo Method. International Business Information Management Association (IBIMA). Rome, Italy, Nov.13-14, pp. 1402-1411.

Dostál, P. (2011) Advanced Decision Making in Business and Public Services, CERM. Brno.

Dvořák, D., Kališ, J., Sirůček, J. (2011) Mistrovství v Microsoft Project 2010, Computer Press, Brno. (in Czech)

Goldratt, E. M. (2011) Kritický řetěz, InterQuality, Praha. (in Czech)

IPMA. (2006) ICB - IPMA Competence Baseline, Version 3.0. Nijkerk, Netherlands. http://www.ipma.ch/assets/ICB3.pdf

Joslin, R., Müller, R. (2015) Relationships between a project management methodology and project success in different project governance contexts. International Journal of Project Management. DOI: 10.1016/j.ijproman.2015.03.005

Jugdev, K., Müller, R. (2005). A retrospective look at our evolving understanding of project success. Project Management Journal. 36 (4). pp. 19-31. DOI: http://hdl.handle.net/2149/277

Kemmeter, S. (2014) By Controlling for Project Success - Partnership Strategies for Controller and Manager. Betriebswirtschaftliche Forschung und Praxis. 66 (5). pp. 579-580.

Khan, A. S., Rasheed, F. (2015) Human resource management practices and project success, a moderating role of Islamic Work Ethics in Pakistani project-based organizations. International Journal of Project Management. 33 (2). pp. 435-445. DOI: 10.1016/j.ijproman.2014.08.006

Kloppenborg, T. J., Tesch, D., Manolis, Ch. (2014) Project Success and Executive Sponsor Behaviors: Empirical Life Cycle Stage Investigations. Project Management Journal. 45 (1). pp. 9-20. DOI: 10.1002/pmj.21396

Koleňák, J., Smolíková, L. (2012) Use of the Instruments of Project Management in Business Practice in the Czech Republic, In International Conference Trends in Economics and Management for the 21st Century. Brno, Czcech Republic, pp. 1-8.

Koleňák, J., Smolíková, L. (2013) The Use of Project Management Tools in the Czech Republic. Trendy Ekonomiky a Managementu. 7 (3). pp. 68-75.

Kropáč, J. (2007) STATISTIKA B, Jednorozměrné a dvourozměrné datové soubory, Regresní analýza, Časové řady, RNDr. Jiří Kropáč. (in Czech)

Kubálek, T., Kubálková, M. (2010) Rízení projektů v Microsoft Project 2010, Computer Press, Brno. (in Czech)

Kuchta, D. (2001) Use of Fuzzy numbers in project risk (criticality) assessment. International Journal of Project Management. 19 (5). pp. $305-$ 310. DOI: 10.1016/S0263-7863(00)00022-3

Lacko, B. (2001) Modelování a simulace v oblasti projektového řízení, In Sbornik semináře Modelování a simulace projektů - MSP. Brno, Czech Republic. (in Czech)

Mazur, A., Pisarski, A., Chang, A. Ashkanasy, N. M. (2014) Rating defence major project success: The role of personal attributes and stakeholder relationships. International Journal of Project Management. 32 (6). pp. 944-957. DOI: 10.1016/j.ijproman.2013.10.018

McKay, D. S., Ellis, T. J. (2014) Tracking the Flow of Knowledge in IT organizations; The Impact of Organizational Learning Factors and Project Learning Practices on Project Success. In: 47th Hawaii International Conference on System Sciences (HICSS). Waikoloa, HI, Jan. 6-9, pp. 5185-5194. DOI: 10.1109/HICSS.2014.648 
Müller, R., Turner, R. (2007) The influence of project managers on project success criteria and project success by type of project. European Management Journal. 25 (4). pp. 298-309. DOI: 10.1016/j.emj.2007.06.003

Naeni, L.M., Shadrokh, S., Salehipour, A. (2011) A fuzzy approach for the earned value managemen. International Journal of Project Management. 29 (6). pp. 764-772. DOI: 10.1016/j.ijproman.2010.07.012

Nieto-Morote, A., Ruz-Vila, F. (2011) A fuzzy approach to construction project risk assessment. International Journal of Project Management. 29 (2). pp. 220-231. DOI: 10.1016/j.ijproman.2010.02.002

Oliveros, A. V. O., Fayek, A. R. (2005) Fuzzy Logic Approach for Activity Delay Analysis and Schedule Updating. Journal of Construction Engineering and Management. 131 (1). pp. 42-51.

DOI: 10.1061/(ASCE)0733-9364(2005)131:1(42)

Pérez, J. G., Rambaud, S. C., García, L. B. G. (2005) The two-sided power distribution for the treatment of the uncertainty in PERT. Statistical Methods and Applications. 14 (2). pp. 209-222.

DOI: $10.1007 / \mathrm{s} 10260-005-0115-9$

PMI. (2013) A Guide to the PM body of knowledge. (5th ed.), Pennsylvania, USA.

Relich, M. (2013) Knowledge Acquisition for New Product Development with the Use of an ERP Database. Proceedings of the 2013 Federated Conference on Computer Science and Information Systems. Krakow, Poland, Sept. 8-11, pp. 1285-1290.

Relich, M. (2015) A computational intelligence approach to predicting new product success. Proceedings of the 11th International Conference on Strategic Management and its Support by Information Systems, pp. 142-150.

Relich, M., Muszyński, W. (2014) The use of intelligent systems for planning and scheduling of product development projects. 18th International Conference on Knowledge-Based and Intelligent Information \& Engineering Systems - KES-2014. pp. 1586-1595. DOI: 10.1016/j.procs.2014.08.242

Rosenau, M. (2007) Řizení projekti̊ - príklady, teorie, praxe, Computer Press, Brno. (in Czech)
Sanjuan, A. G., Froese, T. (2013) The Application of Project Management Standards and Success Factors to the Development of a Project Management Assessment Tool. Procedia - Social and Behavioral Sciences. 74 (29). pp. 91-100. DOI: 10.1016/j.sbspro.2013.03.035

Saunders, M., Lewis, P., Thornhill, A. (2009) Research methods for business students, Son Education Limited, Edinburgh.

Schibi, O. (2013) Managing Stakeholder Expectations for Project Success: A Knowledge Integration Framework and Value Focused Approach, USA.

Serra, C. E. M., Kunc, M. (2015) Benefits Realisation Management and its influence on project success and on the execution of business strategies. International Journal of Project Management. 33 (1). pp. 53-66.

DOI: 10.1016/j.ijproman.2014.03.01

Serrador, P., Pinto, J. K. (2015) Does Agile work? - A quantitative analysis of agile project success. International Journal of Project Management. 33 (5). pp. 1040-1051. DOI: 10.1016/j.ijproman.2015.01.006

Tamay, S., Gage, S. (2012) Integrated Project Management Tool for Modeling and Simulation of Complex Systems. AIAA Modeling and Simulation Technologies Conference. Minneapolis, Minnesota, Aug. 13-16.

Technologický profil ČR. Databáze kontaktů pro spolupráci v inovačním podnikání. Asociace inovačního podnikání v ČR, Czech Republic. (in Czech) URL: http://www.techprofil.cz/find.asp?action=SubjectsByCounty\&ID $=10 \&$ SearchBy $=\% 2 \mathrm{D} \% 2 \mathrm{DVyso} \%$ E8ina + Region

Todorović, M. L., Dejan, Č. P., Mihić, M. M., Obradović, V. L., Bushuyev, S. D. (2015) Project success analysis framework: A knowledge-based approach in project management. International Journal of Project Management. 33 (4). pp. 772-783. DOI: 10.1016/j.ijproman.2014.10.009

Zadeh, L. A. (1965) Fuzzy sets. Information and Control. 8 (3). pp. 338-353. DOI: 10.1016/S0019-9958(65)90241-X

Zimmermann, H. J. (2001) Fuzzy Set Theory - and Its Applications. Kluwer Academic Publishers, London. 